\title{
MOLECULAR CHARACTERIZATION OF TWO ROCIO FLAVIVIRUS STRAINS ISOLATED DURING THE ENCEPHALITIS EPIDEMIC IN SÃO PAULO STATE, BRAZIL AND THE DEVELOPMENT OF A ONE-STEP RT-PCR ASSAY FOR DIAGNOSIS*
}

Terezinha Lisieux Moraes COIMbra(1), Raimundo N. SANTOS(1), Selma PETRELLA(1), Teresa Keico NAGASSE-SUGAHARA(2), Silvana Beres CASTRIGNANO(3) \& Cecília L. Simões SANTOS(2)

\begin{abstract}
SUMMARY
Rocio virus (ROCV) was responsible for an explosive encephalitis epidemic in the 1970s affecting about 1,000 residents of 20 coastland counties in São Paulo State, Brazil. ROCV was first isolated in 1975 from the cerebellum of a fatal human case of encephalitis. Clinical manifestations of the illness are similar to those described for St. Louis encephalitis. ROCV shows intense antigenic cross-reactivity with Japanese encephalitis complex (JEC) viruses, particularly with Ilheus (ILHV), St. Louis encephalitis, Murray Valley and West Nile viruses. In this study, we report a specific RT-PCR assay for ROCV diagnosis and the molecular characterization of the SPAn37630 and SPH37623 strains. Partial nucleotide sequences of NS5 and E genes determined from both strains were used in phylogenetic analysis. The results indicated that these strains are closely related to JEC viruses, but forming a distinct subclade together with ILHV, in accordance with results recently reported by MEDEIROS et al. (2007).
\end{abstract}

KEYWORDS: Rocio virus; RT-PCR; Phylogenetic analysis; Disease diagnosis.

\section{INTRODUCTION}

For the first time in history, during 1975-77, the flavivirus named Rocio virus (ROCV) was responsible for a severe epidemic of viral encephalitis that affected several residents of 20 coastland counties in southern São Paulo State, Brazil ${ }^{16}$. The epidemic spread to seven communities of the Baixada Santista and 13 in the Vale do Ribeira. Retrospective studies based on clinical and serological data suggested that encephalitis caused by ROCV had already occurred in 1973 and 1974. Observations of the characteristic sequelae of ROCV encephalitis in seven people that had febrile illness at that time, as well as positive serology in pre-epidemic sera of three people, support the above hypothesis ${ }^{16,17}$.

It was estimated that 1,000 human infections occurred, with approximately 100 deaths and serious neurological sequelae in $20 \%$ of the survivors, especially motor function and equilibrium deficits ${ }^{4,7,17,18}$. Lethality during the epidemic was estimated to be $30 \%$ in patients under one year and over 60 years of age, with an overall case-fatality rate of $10 \%$. However, during the operation period of the emergency hospital installed in Itanhaém County, the lethality rate was around $5 \%$ 6,17,18,29.

The main clinical manifestations of the disease were headache, fever, vomiting, weakness, anorexia, abdominal distention, nausea, hyperemia of the oropharynx and conjunctivae. Other symptoms included myalgia, urinary retention, photophobia, unexplained mastication, lacrimation, aerophobia and falling. Predominant meningoencephalitis signs included meningeal irritation, consciousness alterations, reflex disturbances, motor impairment, dyslalia and convulsions ${ }^{18,29}$.

Transmission of the virus was associated with close contact of man with forest environment, and most of the cases were seen in younger males of productive age (from 15 to 30 years) who were involved in agricultural activities. The ecology of the viral transmission cycle remains unknown but there is strong evidence indicating that birds and mosquitoes may be involved $\mathrm{d}^{6,7,8,12,17,21}$.

ROCV is a member of the Flaviviridae family, genus Flavivirus that comprises more than 70 members, 40 of which of medical importance $^{22}$. The genus is serologically divided into eight antigenic complexes and nine individual serotypes ${ }^{3,19,31}$. Many of these viruses, such as Dengue (DENV), Yellow Fever (YFV), Japanese encephalitis (JEV), St. Louis encephalitis (SLEV), and West Nile encephalitis (WNV) are associated with extensive morbidity and mortality. They cause encephalitic, hemorrhagic, hepatic, and febrile illnesses in humans and other vertebrates ${ }^{22,31}$.

Flaviviruses are spherical enveloped particles of about $45 \mathrm{~nm}$ in diameter, with a single-stranded linear positive sense RNA genome of

\footnotetext{
*This work is part of Terezinha L.M. Coimbra's MSc thesis, defended at the Coordenação dos Institutos de Pesquisa da Secretaria de Estado da Saúde de São Paulo, SP, Brazil, in 2004. (1) Seção de Vírus Transmitidos por Artrópodos, Instituto Adolfo Lutz, São Paulo, SP, Brasil.

(2) Laboratório de Biologia Molecular, Instituto Adolfo Lutz, São Paulo, SP, Brasil.

(3) Seção de Vírus Produtores de Exantemas, Instituto Adolfo Lutz, São Paulo, SP, Brasil.

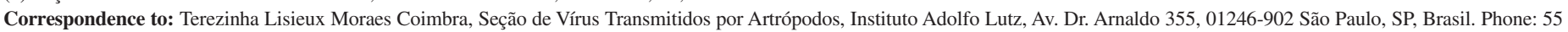
11 3068-2902, Fax: 5511 3085-3505. E-mail: tesugaha@ial.sp.gov.br; keicos@hotmail.com; licoimbra@ial.sp.gov.br; tlicoimbra@hotmail.com
} 


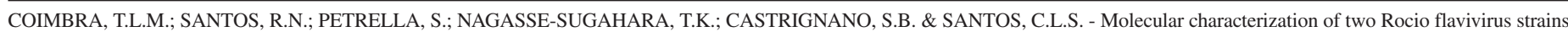
isolated during the encephalitis epidemic in São Paulo State, Brazil and the development of a one-step RT-PCR assay for diagnosis. Rev. Inst. Med. trop. S. Paulo, 50(2): 89-94, 2008.

about $11 \mathrm{~kb}$ that encodes three structural [capsid (C), membrane (M), envelope (E)] and seven nonstructural proteins [NS1, NS2A, NS2B, NS3, NS4A, NS4B, NS5 $]^{22}$. The complete genome of ROCV was determined to be 10,794 nucleotides (nt) in length with a unique open reading frame (ORF) of 10,275 nt that is flanked by a 5'- and a 3' - non coding regions of 92 and $427 \mathrm{nt}$, respectively ${ }^{20}$. Up to now, only one ROCV strain had its genome partial ${ }^{13,19}$ and totally ${ }^{20}$ sequenced, and it is known as ROCV prototype strain or SPH34675. It was isolated in December 1975 from the cerebellum and upper spinal cord of a 39year-old farmhand who lived in Rocio district, Iguape County, São Paulo State, Brazil. This man died five days after the onset of encephalitis. Subsequently, 13 more ROCV strains were isolated during the epidemic period, nine from autopsied human brain specimens, two from sentinel mice, one from the blood of a bird (Zonotrichia capensis)

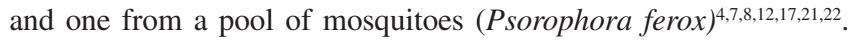

In this study, we report a specific RT-PCR for ROCV diagnosis and the molecular characterization of two ROCV strains that had never had their genomes sequenced, one from a sentinel mouse and another from a patient, both isolated at Adolfo Lutz Institute, São Paulo State, Brazil. This characterization was based on phylogenetic analysis of partial E and NS5 genes sequences of the virus.

\section{MATERIAL AND METHODS}

Viruses: Two strains of ROCV, SPAn37630, isolated on 02/28/ 1976 from a sentinel mouse exposed to the Cananéia County forest $\left(25^{\circ} \mathrm{S}, 48^{\circ} \mathrm{W}\right)$, and SPH37623, obtained on 03/29/1976 from an autopsied human brain specimen were selected for molecular characterization. They were primarily isolated in suckling mice brain and their brain extracts were maintained lyophilized at $-20{ }^{\circ} \mathrm{C}$ since then, for almost 30 years. For the experiment, these two virus stocks were re-hydrated and inoculated again in suckling mice brain.

The following flaviviruses obtained from the collection of the Arthropod-Transmitted Viruses Section, Adolfo Lutz Institute, were included in this study in order to evaluate the RT-PCR specificity: Iguape (IGUV), Ilheus (ILHV), Dengue type 1 (DENV-1), Dengue type 2 (DENV-2), SLEV, YFV wild and YFV vaccine strains. DENV-2 (SPH184229) and YFV vaccine strain (SPH-184873) were grown in Aedes albopictus $\mathrm{C} 6 / 36$ cell culture and the other viruses were maintained in suckling mice brain passages.

The criteria utilized to choose the above flaviviruses were based on high prevalence of the viruses circulating in our environment (IGU, SLEV, DENV, YFV), closely related viruses that present serological cross-reactivity (SLEV, ILHV) and those of major medical importance in our country (DEN and YFV).

Primers, one-step RT-PCR and nucleotide sequencing: Specific pairs of ROCV primers utilized in this study were designed in our laboratory by using the Primer Select software (DNASTAR Inc., Madison, Wis. USA). They were deduced from E and NS5 genes based on sequences of ROCV prototype, available in GenBank with accession numbers AF372409 and AF013397, respectively (Table 1). The primer pairs $(\mathrm{E} 1 / \mathrm{E} 2, \mathrm{E} 3 / \mathrm{E} 4, \mathrm{~N} 1 / \mathrm{N} 2$, and $\mathrm{N} 3 / \mathrm{N} 4)$, were chosen in order that the two amplified sequences of each gene might overlap in certain extent within their respective genes.
Table 1

Sequences of specific primers used in RT-PCR for ROCV

\begin{tabular}{llll}
\hline Primer $^{\mathrm{a}}$ & Sequence $\left(5^{\prime \prime} \rightarrow 3^{\prime}\right)$ & Gene & $\begin{array}{l}\text { Genomic } \\
\text { position }\end{array}$ \\
\hline E1 (F) & GAATGACCATCCAGCGTGAAAAT & E & 1235 \\
E2 (R) & TCCGGCTAGAGCAGTATGAAGTG & E & 1659 \\
E3 (F) & GCACACGCTACAAGGCAAACC & E & 1588 \\
E4 (R) & CCCGATCACACTACCAGACTTATG & E & 2070 \\
N1 (F) & AGAGAATTCATATGGGGGAGTAG & NS5 & 9066 \\
N2 (R) & TTCAGAAAATGGAGAGCAGTTG & NS5 & 9620 \\
N3 (F) & ATGCCCTAAACACCTACACCAATC & NS5 & 9389 \\
N4 (R) & CCAGTCGGAACCCAGTCAAT & NS5 & 9947 \\
\hline
\end{tabular}

${ }^{\mathrm{a}} \mathrm{F}$, forward primer; $\mathrm{R}$, reverse primer; ${ }^{\mathrm{b}}$ The number corresponds to the nucleotide position in the deposited open reading frame of ROCV genome (GenBank AY632542), corresponding to the first (5') base of each primer.

The viral RNA was extracted from infected brain or cell culture by using the QIAmp RNA Blood Mini Kit (Qiagen Inc., CA, USA) following the manufacturer's instructions.

Amplification of RNA was performed by one-step RT-PCR as previously described ${ }^{26}$ with some modifications. Briefly, the reactions were performed in a total volume of $30 \mu \mathrm{L}$ containing 12 pmol of each primer; 0.25U AMV reverse transcriptase (Promega); $1.2 \mathrm{U}$ Taq DNA polymerase (Invitrogen); $20 \mathrm{mM}$ Tris, $\mathrm{pH} 8.4 ; 50 \mathrm{mM} \mathrm{KCl} ; 1.8 \mathrm{mM}$ $\mathrm{MgCl}_{2} ; 0.2 \mathrm{mM}$ deoxynucleoside triphosphates (dATP, dCTP, dGTP and dTTP) (Invitrogen) and $1 \mu \mathrm{L}$ of extracted RNA which was then submitted to one RT cycle of $41{ }^{\circ} \mathrm{C}$ for one hour followed by 35 cycles of $93{ }^{\circ} \mathrm{C}$ for $30 \mathrm{~s} ; 55^{\circ} \mathrm{C}$ for $30 \mathrm{~s} ; 72{ }^{\circ} \mathrm{C}$ for $90 \mathrm{~s}$, and a final extension at $72{ }^{\circ} \mathrm{C}$ for five min. The amplification products were visualized under UV light after electrophoresis in $1.5 \%$ agarose gel stained with ethidium bromide ${ }^{24}$.

The amplicons were directly sequenced using the ABI Prism ${ }^{\mathrm{R}}$ BigDye $^{\mathrm{M}}$ Terminator Cycle Sequencing Ready Reaction Kit (Applied Biosystems, Foster City, CA, USA) according to the manufacturer's protocol. The sequences were determined in an automated $377 \mathrm{ABI}$ sequencer (Applied Biosystems, Foster City, CA, USA) and subsequently edited by using the software Sequence Navigator v 1.0 (Applied Biosystems).

Phylogenetic analysis: The SEQMAN software (DNASTAR, Inc., Madison, Wis., USA) was used to assemble the E1/E2 and E3/E4 sequences in order to obtain a more extensive contiguous sequence. The same was done with N1/N2 and N3/N4 sequences. These contigs of $\mathrm{E}$ and NS5 gene of ROCV and sequences of other flaviviruses obtained from GenBank (Table 2) were aligned by using the multiple sequence alignment method implemented in Clustal $\mathrm{X}^{28}$ and BioEdit Sequence Alignment Editor ${ }^{15}$. The EDITSEQ and MEGALIGN softwares (DNASTAR, Inc., Madison, Wis., USA) were used to deduce the amino acid (aa) sequences and to calculate the identity between the analyzed sequences. The sequences obtained in this study were deposited in GenBank with the accession numbers AY739902 to AY739905 (Table 2). The phylogenetic relationships of the sequences determined in this study were performed with the maximum parsimony (MP) method ${ }^{11}$ implemented in PAUP $4.0 \mathrm{~b} 10$ software $^{27}$ with the heuristic search option, TBR branch-swapping and unweighted 


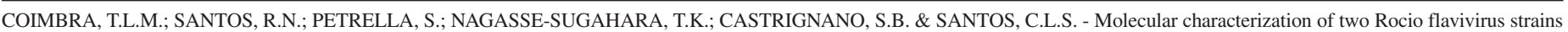
isolated during the encephalitis epidemic in São Paulo State, Brazil and the development of a one-step RT-PCR assay for diagnosis. Rev. Inst. Med. trop. S. Paulo, 50(2): 89-94, 2008.

Table 2

Viruses used in the phylogenetic study

\begin{tabular}{llll}
\hline Virus (abbreviation) & Strain & NS5 gene & GenBank accession no. \\
& & AF013360 & AF372406 \\
\hline Alfuy (ALFV) & MRM-3929 & AF013367 & AF372417 \\
Cacipacore (CPCV) & BeAn 327600 & M87512 & M87512 \\
Dengue-1 (DENV-1) & Singapore & AF038403 & L10045 \\
Dengue-2 (DENV-2) & New Guinea & M93130 & M93130 \\
Dengue-3 (DENV-3) & H-87 & M14931 & M14931 \\
Dengue-4 (DENV-4) & Original & AF013376 & AF372414 \\
Ilheus (ILHV) & AS-14 & U15763 & M18370 \\
Japanese Enc. (JEV) & MRM-61C & D00246 & D00246 \\
Kungin (KUNV) & Enc.(MVE) original & AF013389 & M24220 \\
Murray Valley (MVEV) & SPH 34675 & AF013397 & AF372409 \\
Rocio (ROCV) & SPAn 37630 & AY739904 & AY739902 \\
Rocio (ROCV) & SPH 37623 & AY739905 & AY739903 \\
Rocio (ROCV) & MSI-7 & AF013416 & M16614 \\
St. Louis Enc.(SLEV) & EG-101 & M12294 & M12294 \\
West Nile (WNV) & Pasteur 17D-204 & X15062 & X15062 \\
Yellow Fever (YFV) & - & M91671 & M91671 \\
Cell fusing agent (CFA) & - & & \\
\hline
\end{tabular}

characters. Bootstrapping ${ }^{10}$ utilized 1,000 pseudoreplicates, with ten random-taxon-addition replicates per pseudoreplicate; parsimonyuninformative characters were excluded from all the analyses. The cell fusing agent virus (CFA) was included in the phylogenetic analysis as the outgroup reference.

\section{RESULTS}

One-step RT-PCR with specific primers for ROCV: All the four primer pairs designed in this study succeeded in amplifying the extracted RNA from ROCV strains yielding fragments of the expected size as follows: 425 bp (E1/E2), 483 bp (E3/E4), 555 bp (N1/N2) and 559 bp (N3/N4). Although the primer set E3/E4 had yielded a very strong DNA band of the expected length, other weak bands also appeared in the agarose gel. The other three primer sets were able to amplify only a single band with the virus samples, but E1/E2 and N3/ N4 amplified some unspecific weak bands with uninfected mouse brain control. These weak bands probably represent misprimings to mRNA encoded by mouse DNA (Fig. 1).

To evaluate the specificity of the RT-PCR with the chosen N1/N2 primer set, RNAs extracted from seven distinct flaviviruses (IGUV, ILHV, SLEV, DENV-1, DENV-2, YFV wild and YFV vaccine strain) were tested and all of them resulted negative.

Phylogenetic analysis: The partial E and NS5 sequences obtained in this work were compared with the ROCV prototype strain sequences AF372409 and AF013397, respectively. The comparison showed a very high identity between them. In relation to nucleotide sequences, the paired identity for E gene was $99.8 \%$ and ranged from $99.5 \%-99.9 \%$ for NS5 gene. The analyses of amino acid sequences revealed identities ranging from $99.3 \%-99.6 \%$ and $99.0 \%-100 \%$ for E and NS5 genes, respectively.

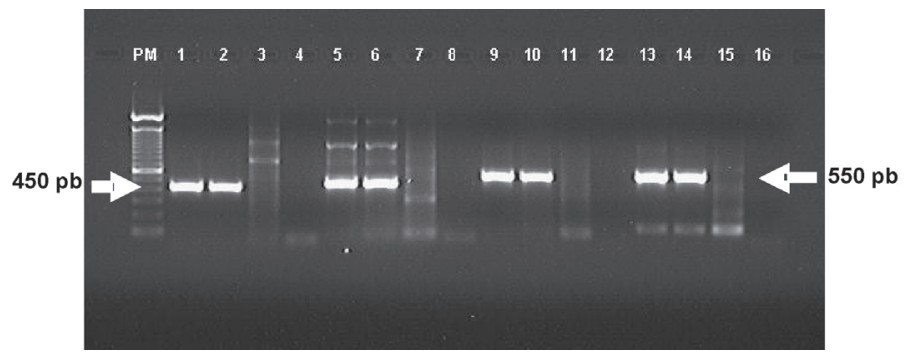

Fig. 1 - Agarose gel electrophoresis analysis of one-step RT-PCR products from RNA extracted from mouse brain infected with strains SPAn37630 and SPH37623 using specific primers for E and NS5 genes regions of ROCV. (PM): 100bp DNA ladder (Invitrogen ${ }^{\mathrm{TM}}$, Carlsbad, CA, USA); Lanes 1-8: RT-PCR for E gene; Lanes 1-4: RT-PCR using the set primers E1/E2; (1): SPAn37630; (2): SPH37623; (3) Brain of uninfected mouse; (4): Negative control (H2O); Lanes 5-8: RT-PCR using the set primers E3/E4; (5): SPAn37630; (6): SPH37623; (7): Brain of uninfected mouse; (8): Negative control (H2O); Lanes 9-16: RT-PCR for NS5 gene; Lanes 9-12: RT-PCR using the set primers N1/N2; (9): SPAn37630; (10): SPH37623; (11): Brain of uninfected mouse; (12): Negative control (H2O); Lanes 13-16: RT-PCR using the set primers N3/N4; (13): SPAn37630; (14): SPH37623; (15): Brain of uninfected mouse; (16): Negative control (H2O).

The phylogenetic trees constructed by MP analysis of partial nucleotide sequences of E (816 nt) and NS5 gene (864 nt) and other flaviviruses are shown in Figures 2 and 3, respectively. The results showed that SPAn37630, SPH37623 and ROCV prototype formed a monophyletic group closely related to JEV complex viruses but segregated in a subclade with ILHV.

\section{DISCUSSION}

ROCV is considered a classical emerging virus of focal incidence in the Americas. For the first time in history, from 1975 to 1977, the new flavivirus was responsible for a severe and extensive encephalitis epidemic in the southeastern coast of the São Paulo State, Brazil 6,7,17,22,29. 


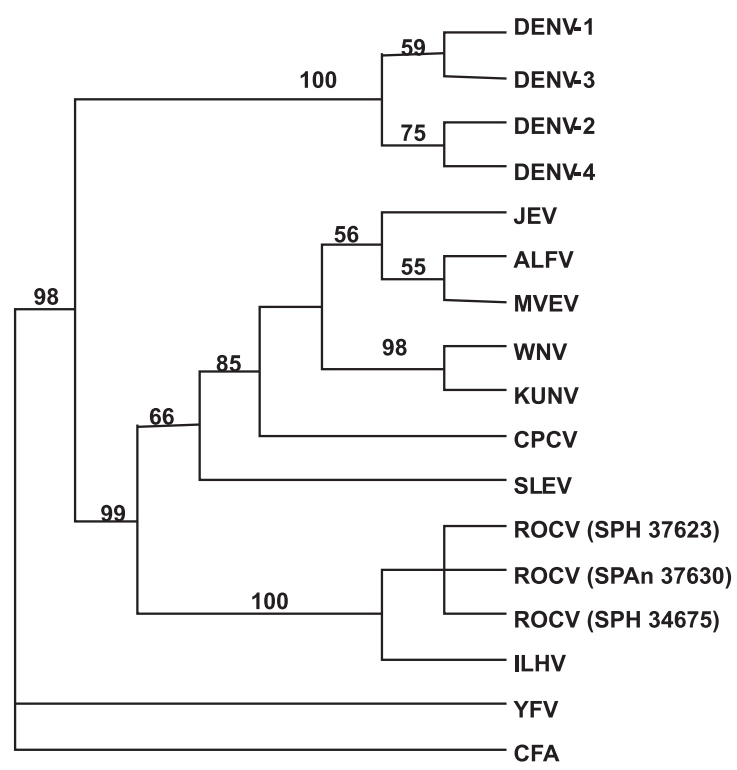

Fig. 2 - Phylogram generated by MP analysis of the partial nucleotide sequences of the $\mathrm{E}$ gene of ROC viruses and other flaviviruses obtained from GeneBank (Tab. 2). Each number of node indicates bootstrap support values (1,000 replicates). CFA virus was used as outgroup.

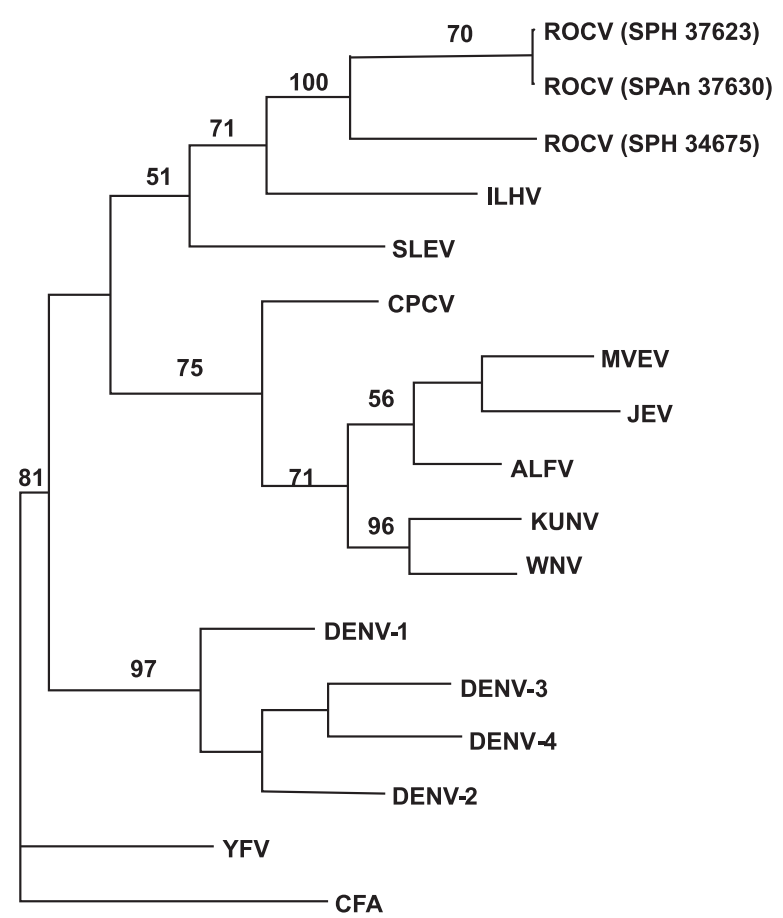

Fig. 3 - Phylogram generated by MP analysis of the partial nucleotide sequences of the NS5 gene of ROC viruses and other flaviviruses obtained from GeneBank. Each number of node indicates bootstrap support values (1,000 replicates). CFA virus was used as outgroup.

The ecology of the viral transmission cycle of ROCV remains unknown but there is strong evidence indicating that birds and mosquitoes are involved $7,8,12,17,18,21,22$. During the epidemic period, the dominant geographic area was the forest, inhabited predominantly by rural population. Consequently, the reemergence of this virus is possible. We remain vulnerable to a wide array of new and resurgent infectious diseases due to ecologic changes, such as deforestation or reforestation, which increase the exposure of human population to insects, animals, or environmental sources that may harbor new or unusual infectious agents. Notably, several arboviruses are able to reappear in areas after long periods of quiescence (ecologic niche). In this context, humans (agriculture workers engaged in forest activities) may be infected tangentially by the bite of infected arthropods when they enter in contact with an ecologic niche, resulting in few or sporadic cases. Therefore, arboviruses are essentially zoonoses, but environmental modifications can facilitate the occurrence of human infections. It is noteworthy to bear in mind that the human being is an incidental host in a dead-end cycle or an active reservoir host causing other human infections (urban cycle $^{30}$. Therefore, the isolations from humans provide little information about ecoepidemiology of arboviruses. Besides this serious situation, there is no specific treatment or vaccines available for this disease. Medical and expert nursing care is based mainly on symptomatic therapy aimed to maintain vital functions.

Concerning emerging viruses, it is convenient to consider the emerging epidemic caused by WNV in New York in 1999. The virus spread to neighboring states in the northeastern United States leading to human fatal cases and extensive avian mortality. Intensive surveillance was instituted to monitor the spread of virus among mosquitoes, birds, and other vertebrates. It was evident that the rapid identification of the agent involved in the epidemic greatly contributed to its control. Likewise, ROCV may reappear causing catastrophic consequences the same way as WNV in the USA. The finding of antibodies to ROCV in eight patients, in the state of Bahia $(1,200 \mathrm{Km}$ from São Paulo) 20 years after the only ROCV epidemic, indicates that the virus was still circulating and that it had probably been carried by migratory birds ${ }^{25}$.

The possibility of reemergence of ROCV in a near future maintains the interest in the study of the virus and in the development of new laboratory techniques to detect $\mathrm{it}^{5,14,20,23}$.

Nucleic acid-based techniques, especially RT-PCR, which have the advantages of speed, specificity, and sensitivity can be used to detect these arboviric infections. Furthermore, extensive cross-reactions among the flaviviruses make the identification by conventional serologic methods very difficult.

In the present study, with four primer pairs designed, we succeeded in obtaining an $816 \mathrm{nt}$ sequence of $\mathrm{E}$ gene and an $864 \mathrm{nt}$ sequence of NS5 gene from two ROCV strains. The high genetic similarity among the strains isolated from humans (the prototype strain and SPH37623) and from sentinel mouse (SPAn37630), although theoretically predictable since they were isolated during the same epidemic, is documented in this study for the first time. The similarities of the partial genomic sequences of the two previously unsequenced strains in relation to the prototype strain are important to attest the genomic stability of the virus, and the differences among them can be used in the future in comparison to new strains if ROCV reemerges.

The set of primers N1/N2 was chosen to be further studied in relation to specificity once the amplicons yielded strong bands and did 


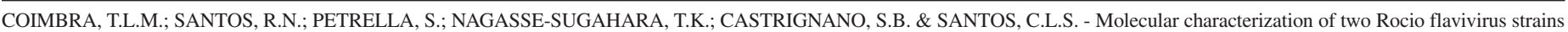

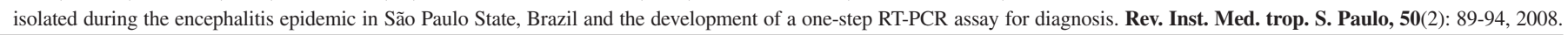

not present unspecific bands, neither with the uninfected mouse brain nor with the viral samples. The specificity tests showed that the developed one-step RT-PCR with this primer set was very satisfactory, resulting negative for all the other flaviviruses tested, indicating that this assay can be used for diagnostic purposes and for surveillance of Rocio encephalitis.

The phylogenetic trees generated by MP analysis with ROCV partial nucleotide sequences of E and NS5 genes indicated that they are closely related to JEC viruses ${ }^{1,2,13,19}$ but forming a distinct subclade together with ILHV in accordance with results recently reported by MEDEIROS et al. ${ }^{20}$. Complementing previous antigenic classification ${ }^{3,22}$, molecular studies are contributing to better allocate ROCV within Flaviviruses taxonomy.

\section{RESUMO}

Caracterização molecular de duas cepas do flavivírus Rocio, isoladas durante a epidemia de encefalite no Estado de São Paulo, Brasil e desenvolvimento do teste one-step RT-PCR para diagnóstico

O vírus Rocio (ROCV) foi responsável por uma explosiva epidemia de encefalite que ocorreu nos anos 70 afetando cerca de 1.000 habitantes de 20 municípios litorâneos do Estado de São Paulo, Brasil. ROCV foi isolado em 1975 de cerebelo de caso humano fatal de encefalite. As manifestações clínicas da doença são semelhantes àquelas descritas para encefalite St. Louis. ROCV apresenta intensa reatividade cruzada com os vírus do Complexo da Encefalite Japonesa (JEV), particularmente com o vírus Ilhéus (ILHV) e com os vírus das encefalites St. Louis, Murray Valley e West Nile. Neste estudo, relatamos o desenvolvimento de um teste de RT-PCR específico para diagnóstico de ROCV e a caracterização molecular das cepas SPAn37630 e SPH37623. Foi realizada a análise filogenética das sequiências parciais dos genes NS5 e E, de ambas as cepas. Os resultados indicaram que essas cepas são intimamente relacionadas ao complexo JEV, mas formando um subgrupo com o ILHV, de acordo com os resultados recentemente publicados por MEDEIROS et al. (2007).

\section{ACKNOWLEDGMENTS}

We are grateful to Dr. Maria Anice M. Sallum of Faculty of Public Health, Department of Epidemiology, University of São Paulo, Brazil, for performing the phylogenetic analysis; to Iray Maria Rocco and Jonas José Kisielius for the helpful suggestions and editorial assistance; to Lucy T.A. dos Santos and Regina Celi V.F. Mosetic of the Breeding Animals Section for supplying the suckling mice and to the staff of Section of Arthropod-Transmitted Viruses of Adolfo Lutz Institute for their excellent contributions.

\section{REFERENCES}

1. BALEOTTI, F.G.; MORELI, M.L. \& FIGUEIREDO, L.T.M. - Brazilian flavivirus phylogeny based on NS5. Mem. Inst. Oswaldo Cruz, 98: 379-382, 2003.

2. BATISTA, W.C.; KASHIMA, S.; MARQUES, A.C. \& FIGUEIREDO, L.T.M. Phylogenetic analysis of Brazilian flavivirus using nucleotide sequences of parts of NS5 gene and 3' non-coding regions. Virus Res., 75: 35-42, 2001.
3. CALISHER, C.H.; KARABATSOS, N.; DALRYMPLE, J.M. et al. - Antigenic relationships between flaviviruses as determined by cross-neutralization tests with polyclonal antisera. J. gen. Virol., 70: 37-43, 1989.

4. COIMBRA, T.L.M.; ROCCO, I.M.; SUZUKI, A. et al. - Arthropod-and-rodent-borne viruses detected in São Paulo State, Brazil. In: TRAVASSOS DA ROSA, A.P.A.; VASCONCELOS, P.F.C. \& TRAVASSOS DA ROSA, J.F.S., ed. An overview of arbovirology in Brazil and neighbouring countries. Belém, Instituto Evandro Chagas, 1998. p. 168-176.

5. DE MORAIS BRONZONI, R.V.; BALEOTTI, F.G.; RIBEIRO NOGUEIRA, R.M.; NUNES, M. \& MORAES FIGUEIREDO, L.T. - Duplex reverse transcription-PCR followed by nested PCR assays for detection and identification of Brazilian alphaviruses and flaviviruses. J. clin. Microbiol., 43: 696-702, 2005.

6. DE SOUZA LOPES, O.; de ABREU SACCHETTA, L.; COIMBRA, T.L.M.; PINTO, G.A. \& GLASSER, C.M. - Emergence of a new arbovirus disease in Brazil. II. Epidemiologic studies on 1975 epidemic. Amer. J. Epidem., 108: 394-401, 1978.

7. DE SOUZA LOPES, O.; COIMBRA, T.L.M.; de ABREU SACCHETTA, L.A. \& CALISHER, C.H. - Emergence of a new arbovirus disease in Brazil. I. Isolation and characterization of the etiologic agent, Rocio virus. Amer. J. Epidem., 107: 444449, 1978.

8. DE SOUZA LOPES, O.; de ABREU SACCHETTA, L.; FRANCY, D.B.; JAKOB, W.L. \& CALISHER, C.H. - Emergence of a new arbovirus disease in Brazil. III. Isolation of Rocio from Psorophora ferox (Humboldt, 1819). Amer. J. Epidem., 113: 122125,1981 .

9. ENSERINK, M. - New York's deadly virus may stage a comeback. Science, 287: 2129$2130,2000$.

10. FELSENSTEIN, J. - Confidence limits on phylogenies: an approach using the bootstrap. Evolution, 39: 783-791, 1985

11. FITCH, W.M. - Toward defining the course of evolution: minimum change for a specific tree topology. Syst. Zool., 20: 406-416, 1971.

12. FORATTINI, O.P.; GOMES, A.C.; GALATI, E.A.B.; RABELLO, E.X. \& IVERSSON, L.B. - Estudos ecológicos sobre mosquitos Culicidae no sistema da Serra do Mar, Brasil. Rev. Saúde públ. (S. Paulo), 12: 297-325, 1978.

13. GAUNT, M.W.; SALL, A.A.; LAMBALLERIE, X. et al - Phylogenetic relationships of flaviviruses correlate with their epidemiology, disease association and biogeography. J. gen. Virol., 82: 1867-1876, 2001.

14. GAUNT, M.W. \& GOULD, E.A. - Rapid subgroup identification of the flaviviruses using degenerate primer E-gene RT-PCR and site specific restriction enzyme analysis. J. virol. Meth., 128: 113-127, 2005.

15. HALL, T.A. - BioEdit: a user-friendly biological sequence alignment editor and analysis program for Windows 95/98/NT. Nucleic Acids Symp. Ser., 41: 95-98, 1999.

16. IVERSSON, L.B. - Aspectos da epidemia de encefalite por arbovírus na região do vale do Ribeira, S. Paulo, Brasil, no período de 1975 a 1978. Rev. Saúde públ. (S. Paulo), 14: 9-35, 1980.

17. IVERSSON, L.B. - Rocio encephalitis. In: MONATH, T.P. ed. The arboviruses: epidemiology and ecology. Boca Raton, CRC Press, 1988. v. 4, p. 77-92.

18. IVERSSON, L.B. - Encefalite por arbovírus Rocio. In: FOCACCIA, R., ed. Veronesi: tratado de infectologia. 3. ed. São Paulo, Atheneu, 2005. v. 1, p. 373-379.

19. KUNO, G.; CHANG, G.J.J.; TSUCHIYA, K.R.; KARABATSOS, N. \& CROPP, C.B. Phylogeny of the genus Flavivirus. J. Virol., 72: 73-83, 1998.

20. MEDEIROS, D.B.A.; NUNES, M.R.T.; VASCONCELOS, P.F.C.; CHANG, G.J. \& KUNO, G. - Complete genome characterization of Rocio virus (Flavivirus: Flaviviridae), a Brazilian flavivirus isolated from a fatal case of encephalitis during an epidemic in São Paulo State. J. gen. Virol., 88: 2237-2246, 2007. 
COIMBRA, T.L.M.; SANTOS, R.N.; PETRELLA, S.; NAGASSE-SUGAHARA, T.K.; CASTRIGNANO, S.B. \& SANTOS, C.L.S. - Molecular characterization of two Rocio flavivirus strains isolated during the encephalitis epidemic in São Paulo State, Brazil and the development of a one-step RT-PCR assay for diagnosis. Rev. Inst. Med. trop. S. Paulo, 50(2): 89-94, 2008.

21. MITCHELL, C.J.; MONATH, T.P. \& CROPP, C.B. - Experimental transmission of Rocio virus by mosquitoes. Amer. J. trop. Med. Hyg., 30: 465-472, 1981.

22. MONATH, T.P. - Flaviviruses. In: KNIPE, D.M., ed. Field's Virology. 4. ed. Philadelphia, Lippincott Williams \& Wilkins, 2001. v. 2, p. 1043-1126.

23. MOUREAU, G.; TEMMAM, S.; GONZALES, J.P. et al. - A real-time RT-PCR method for the universal detection and identification of flaviviruses. Vector Borne Zoonotic Dis., 7: 467-477, 2007.

24. SAMBROOK, J. \& RUSSEL, D.W. - Molecular cloning: a laboratory manual. 3. ed. New York, Cold Spring Harbor, 2001. p. 5.10-5.13.

25. STRAATMANN, A.; SANTOS-TORRES, S.; VASCONCELOS, P.F.C. et al. - Evidências sorológicas da circulação do arbovírus Rocio (Flaviviridae) na Bahia. Rev. Soc. bras. Med. trop., 30: 511-515, 1997.

26. SUZUKI, A.; BISORDI, I; LEVIS, S. et al. - Identifying rodent hantavirus reservoirs, Brazil. Emerg. infect. Dis., 10: 2127-2134, 2004.

27. SWOFFORD, D.L. - PAUP*: phylogenetic analysis using parsimony (and other methods). Version 4.0. Sunderland, Sinauer Associates, 2003.
28. THOMPSON, J.D.; GIBSON, T.J.; PLEWNIAK, F.; JEANMOUGIN, F. \& HIGGINS, D.G. - The Clustal $\mathrm{X}$ windows interface: flexible strategies for multiple sequence alignment aided by quality analysis tools. Nucleic Acids Res., 25: 4876-4882, 1997.

29. TIRIBA, A.C.; MIZIARA, A.M.; LOURENÇO, R. et al. - Encefalite humana primária epidêmica observada no litoral sul do Estado de São Paulo. Rev. Ass. méd. bras., 22: 415-420, 1976.

30. VASCONCELOS, P.F.C.; TRAVASSOS DA ROSA, A.P.A.; DÉGALLIER, N.; TRAVASSOS DA ROSA, J.F.S. \& PINHEIRO, F.P. - Clinical and ecoepidemiological situation of human arboviruses in Brazilian Amazonia. Ciênc. e Cult., 44: 117-124, 1992.

31. ZANOTTO, P.M.A.; GOULD, E.A.; GAO, G.F.; HARVEY, P.H. \& HOLMES, E.C. Population dynamics of flavivirus revealed by molecular phylogenies. Proc. nat. Acad. Sci. (Wash.), 93: 548-553, 1996.

Received: 29 October 2007

Accepted: 18 February 2008 